\title{
Obituary
}

\section{B. C. J. G. KNIGHT, 1904-1981}

Bert Cyril James Gabriel Knight died at his home in Cambridge on 29 October 1981 at the age of 77. He was best known for his pioneering work in bacterial nutrition and for his long and devoted service as an Editor of the Journal of General Microbiology. He was also an initiator, an Original Member, and one of only 14 elected Honorary Members of the Society for General Microbiology and he served the Society as an officer continuously for some 27 years, longer than any other person in its history. But he was also, dare one say it in the present context, a mixed culture; for he was a man of letters too, particularly in the realms of 18 th-20th century French and English philosophy and literature.

Knight was born on 4 February 1904 in Reigate, Surrey. He was educated at Reigate Grammar School and at University College, London, where he graduated with a BSc in chemistry in 1925. His first research work was done in the Department of Physical Chemistry at University College under W. E. Garner on the adsorption of aliphatic alcohols on charcoal; for this he was awarded an MSc in 1927. Knight then moved to J. C. Drummond's Department of Biochemistry to work for a year with R. K. Cannan on oxidation-reduction potentials in biological systems followed by a year's independent work on monomolecular films of substances of biological interest. He was the first to use monomolecular film measurements as an aid in the determination of chemical structures. His deduction that batyl and chimyl alcohols were $\alpha$ - and not $\beta$-substituted ethers was subsequently confirmed by Heilbron by chemical synthesis of the components. Many years later in a letter to Drummond, Knight wrote '. . I really was very proud of that bit of work - the first independent idea that really came off - and I often think about those long evenings in that basement room, trying to repair the fine torsion wire on the Adam apparatus, which always broke at critical times'. During this period Knight attended a lecture given by Drummond to postgraduate students about Convoluta roscoffiensis and its photosynthetic symbiont the chlamydomonad Carteria, one of the 'plant-animals' of Frederick Keeble. In the same letter to Drummond, Knight wrote '. . . this fascinated me and from then on I wanted to do biochemistry in relation to microorganisms', and this seems to have set the scene for the next 40 years of Knight's scientific career.

In $1929 \mathrm{Knight}$ joined Fildes at the London Hospital to help with redox potential studies of obligate anaerobes. This was a job for which he was particularly well-suited having worked with Cannan who had himself worked with W. Mansfield Clark on his redox dyes. The initial work established a relationship between the redox potential of the medium and the germination of the spores of Clostridium tetani but the complex (chemically undefined) nature of the medium made it impossible to interpret the effect of the redox potential of the environment on the behaviour of obligate anaerobes. This led to a major change of direction of his researches, viz. to the preparation of chemically defined culture media for bacteria. In the meantime negotiations for the establishment of a new Medical Research Council Unit in Bacterial Chemistry matured and in 1934 the Unit was formally founded to promote a multidisciplinary study of the nutrition of bacteria of medical interest with Fildes as its Director. It was accommodated in three rooms in the Bland Sutton Institute of Pathology in the Middlesex Hospital and Knight moved there, as senior biochemist and Halley Stewart Research Fellow, with Fildes. The other members of the team were the biochemist G. M. Richardson and the bacteriologist G. P. Gladstone, and two technical assistants, L. Packman and D. E. Hughes (who later became Professor of Microbiology at Cardiff). When Richardson left in 1937 he was replaced by H. McIlwain (later to become Professor of Biochemistry at the Institute of Psychiatry of London University) and when Knight moved to the Lister Institute in 1939 he was replaced by D. D. Woods who eventually became Professor of Microbiology at Oxford University. Thus no fewer than four of the seven members of Fildes' team became Professors later in their careers. 
The change of direction of Knight's researches needed a thorough survey of what was already known about the nutritional requirements of bacteria and his search of the literature culminated in his remarkably detailed and comprehensive 182-page monograph in 1936 entitled Bacterial Nutrition. Material for a Comparative Physiology of Bacteria. This must have been an invaluable aid to all who were working in this field at that time. From this compilation he proposed 'a method of classifying different physiological types of bacteria' that was based on the degrees of complexity of the sources of carbon, energy and nitrogen required for growth together with the requirement for 'accessory growth-promoting substances'. This classification was furthermore proposed as 'a suggestion of the lines of bacterial evolution'. One of his main conclusions was that 'increasing nutritional complexity reflects decreasing synthetic ability', meaning in this context a decreased ability to synthesize the specifically required nutrient. At about the same time, and quite independently, Lwoff had come to very similar conclusions from observations made on the nutrition of protozoa and the two studies were mutually supportive. Knight also proposed the important unifying concept that the growth factors are essentials in bacterial growth in general; ; organisms that do not require an exogenous supply of growth factors nevertheless still require them intracellularly - they have not acquired the ability to grow when they are totally absent from the cell. This was in keeping with his observation with Fildes in 1933 that tryptophan was an essential nutrient for several pathogenic bacteria; other bacteria that did not require exogenous tryptophan were able to synthesize it themselves. This concept was reiterated in a paper given by Knight at the 2nd International Congress of Microbiology in London in 1936, at which he was a member of the Sectional Committee for Microbiological Chemistry. During the discussion of his paper it was challenged by Lwoff in connection with the growth factor requirements of parasitic bacteria. Knight in his reply stuck to his guns, maintaining his belief that these requirements were a reflection of the essential need for substances required by bacteria in general but which could in the case of parasitic bacteria be supplied by the host, the parasitic bacterium being unable to make them itself. Subsequently, in 1940, Fildes suggested that the term 'essential metabolite' should replace the various terms essential growth factor, vitamin, nutrilite, etc., to indicate their essential role in the metabolic processes of all organisms.

Knight's 1936 monograph also considered the relationship between the pathogenic nature of an organism and its complex nutrient requirements as well as the mechanism of nutritional variation, in particular the 'training' of microorganisms and the phenomenon of adaptation that had been described a few years earlier by K arström. Some 10 years later Knight was consulted in connection with the proposals made by Lwoff, Van Niel, Ryan and Tatum on the Nomenclature of Nutritional Types of Microorganisms published as an Appendix to the 11th Cold Spring Harbor Symposium in 1946. Much of this system of nomenclature is still widely used today.

In his paper in Nature in April 1937 Knight reported that one of the growth factors present in yeast extract that was required by Staphylococcus aureus could be satisfied by nicotinic acid or nicotinamide. This was the first demonstration of the growth factor (vitamin) activity of these pure compounds in any organism. In the following month's Biochemical Journal he reported that the second growth factor required by $S$. aureus was thiamin and that the organism could now be grown 'in a medium containing only known chemical components'. In his next paper in June 1937 he reported that his colleague Gladstone had obtained identical results with all 12 of the other strains of $S$. aureus that had been tested, and furthermore that the thiamin requirement could be replaced by its pyrimidine and thiazole moieties. The latter observation stimulated other workers to examine other organisms, and examples of protozoa, lower fungi and isolated roots of higher plants were found which could use only the intact thiamin molecule, others were found which could use the moieties when present together, and others which needed to be given only one moiety or the other. These results have implications of course concerning the locus of the lesion in thiamin biosynthesis. The availability of a large number of related pyrimidines and thiazoles prepared by chemists engaged in the synthesis of thiamin allowed Knight and McIlwain to study the specificity of the thiamin components for the growth of S. aureus. Early in 1937 Mueller was examining fractions obtained from $300 \mathrm{~kg}$ ( sic) of liver for their growth factor activity for Corynebacterium diphtheriae. During this operation Knight's paper in Nature on the 


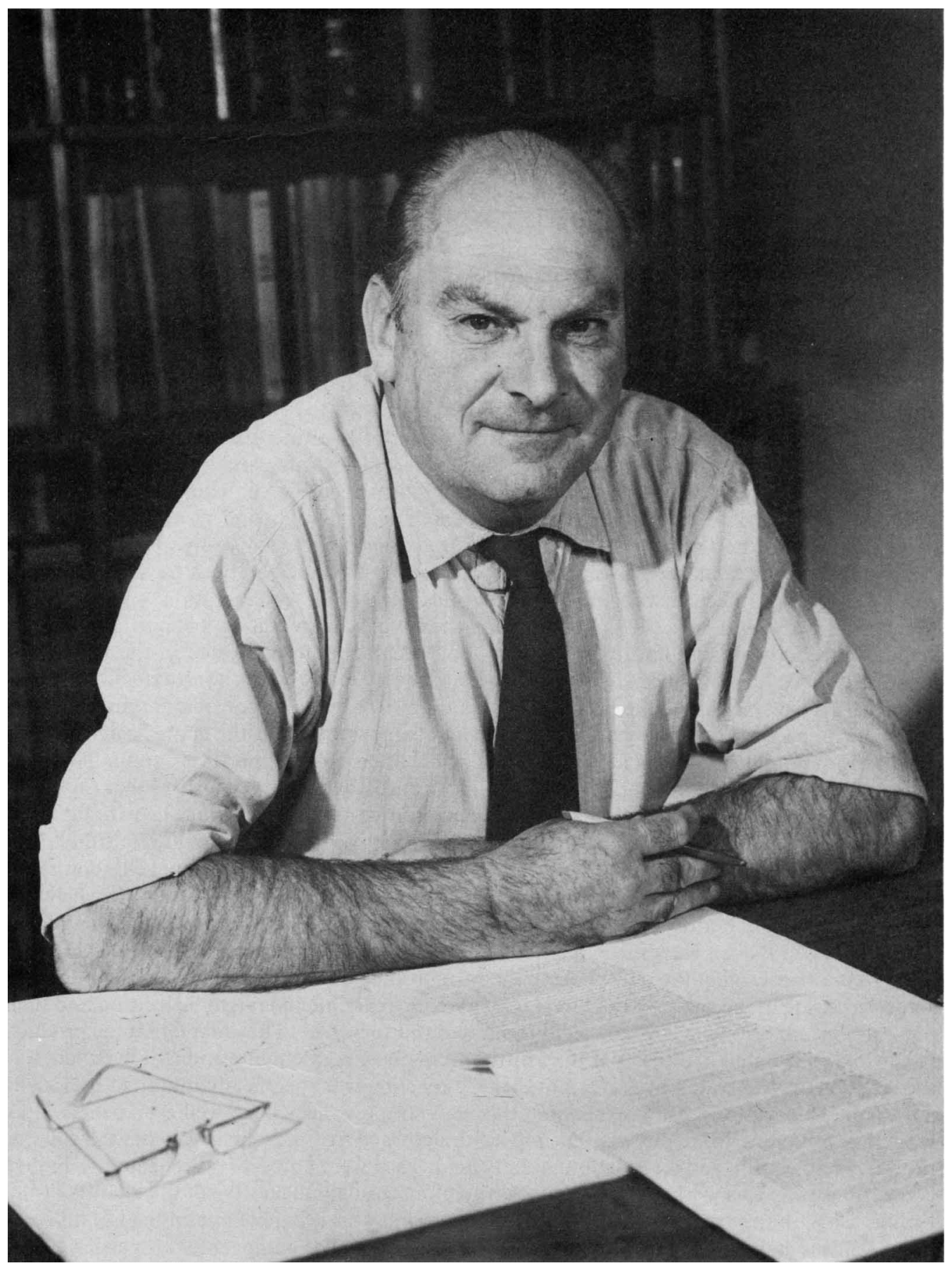

B. C. J. G. KNIGHT, DSC 
growth factor activity of nicotinic acid and nicotinamide was brought to his attention 'in a personal communication' and in August 1937 Mueller identified nicotinic acid as a growth factor for C. diphtheriae. In September 1937 Elvehjem et al. published their observations showing that nicotinic acid cured black tongue in dogs, whilst in November 1937 Juke's group showed for the first time that nicotinic acid caused remission of the symptoms of pellagra in human subjects. The disease pellagra was first described in 1720 and called Mal de la Rosa by Don Gaspar Casal, a Spanish physician practising in the Asturias region of Spain where the disease was endemic. It was thus some 200 years later that Knight's work with $S$. aureus provided the key observations that led to the identification of the factor, or rather the lack of it, that is responsible for the disease; 1937 was a busy and exciting year.

Knight had had no formal training in bacteriology and he relied much on the bacteriological expertise of Gladstone. However, as occasionally occurs in all bacteriology laboratories, an inoculum fails to grow or a culture is found to be contaminated; and we all know how frustrating this can be. On such occasions Knight was most careful to avoid blaming Gladstone directly; he called the events 'acts of providence' . . but he displayed a notice in bold letters in Gladstone's laboratory which read 'Koch bless our inoculum'.

In 1938 Knight obtained his DSc from the University of London in recognition of his work on bacterial nutrition. At the end of that year he moved from the Medical Research Council Unit to become biochemist in the Serum Department at the Lister Institute, Elstree, to work on serum refining and on the production of toxins from various clostridia and from $C$. diphtheriae. However, shortly before the outbreak of war in 1939 the Anaerobic Sub-Committee of the War Wounds Committee of the Medical Research Council invited Knight and W. E. van Heyningen (who was then at the Department of Biochemistry, Cambridge) to investigate the anaerobes Clostridium welchii, Cl.oedematiens and $\mathrm{Cl}$. septicum, whose toxins had been the cause of much gas gangrene in infected wounds during World War I. In collaboration with Marjorie Macfarlane at the Lister, Knight began a study of the methods of purification and standardization of welchii antitoxin but they soon became more interested in the nature and mode of action of the toxin itself. This led to their discovery in 1941 that the $\alpha$-toxin of $\mathrm{Cl}$, welchii was itself an enzyme that hydrolysed lecithin and they were thus responsible for an important landmark in bacterial toxinology. This was the first demonstration of the enzymic activity of a bacterial toxin and of the elucidation of the chemical basis of its mode of action. They had followed up two important leads. First, Nagler in Australia had observed in 1939 that $\mathrm{Cl}$. welchii when grown in human serum produced first an opalescence and then a surface layer of fat in the liquid medium, these phenomena also occurring with a toxin-containing culture filtrate of the organism. Second, R. G. Macfarlane, Oakley and Anderson at the Wellcome Laboratories found in 1941 that an analogous reaction occurs with an emulsion of egg-yolk and they believed that the toxin was liberating fat from a lipoprotein. Macfarlane and Knight used an unpublished method devised by van Heyningen for studying the egg-yolk reaction and found that the toxin converted virtually all of the phosphorus into an acid-soluble form. It occurred to them that the actual substrate in the egg-yolk (and in Nagler's serum experiments) might be lecithin and their preparation and testing of egg-yolk lecithin showed this to be true. They found that the products of the toxin-mediated hydrolysis of the lecithin were phosphorylcholine and a diglyceride, that the reaction was activated by $\mathrm{Ca}^{2+}$, and that the reaction was specifically inhibited by welchii antitoxin. This was a lecithinase reaction that had not previously been well established and it was quite different from the well-known iecithinase activity present in snake venoms that produces lysolecithin and an unsaturated fatty acid. They were however rather cautious in their conclusions from this work: 'The evidence is therefore strongly suggestive of the identity of this lecithinase with the $\alpha$-toxin, though the ultimate proof of this is dependent on the isolation of a homogeneous substrate with the requisite biochemical and pathogenic properties'. They nevertheless calculated that one mouse lethal dose of the toxin could, at its maximum velocity, hydrolyse the whole of its blood lecithin in 2 to 3 hours. The work done by many other workers since 1941, including that done with highly purified $\alpha$-toxin, leaves little doubt that the lecithinase activity of the $\alpha$-toxin is the primary event that results in the syndrome of gas gangrene caused by $\mathrm{Cl}$. welchii (perfringens). It has since been shown that other bacterial toxins 
such as those of diphtheria and cholera possess an enzymic activity and that this is their primary mode of action.

In 1943 Knight and van Heyningen both moved to the Wellcome Laboratories in Beckenham to undertake the large-scale production of purified gas gangrene toxoids for the immunization of the army. They produced many tens of thousands of doses of combined tetanus-welchiioedematiens toxoid which were delivered to the army shortly before D-Day, but too late to be distributed and tested in battle.

As well as this work on toxins and toxoids, Knight was also involved in studies on the microbial production of antibiotics. His knowledge of antibiotics led to his suggestion to Gordon, Martin and Synge that they apply their new technique of partition chromatography on silica gel to the analysis of gramicidin. This resulted in the first determination of the amino acid composition of a naturally occurring polypeptide by this method in 1943.

Whilst at the Wellcome Laboratories Knight, with H. Proom, embarked on a comparative nutritional survey of mesophilic species of the genus Bacillus. In their 1950 paper they concluded that the nutrient requirements of these bacilli were highly characteristic of species, having found that the pattern of nutrient requirements correlated closely with the pattern of conventional characters such as those described by Smith, Gordon and Clark. Interestingly they also found that prolonged laboratory cultivation did not seem to lead to the selection of nutritional variants. In a later paper (1955) Knight added examples, obtained by others, of Haemophilus, the Athiorhodaceae and Bordetella and concluded that it appears that there is now ample evidence to suggest that the nutritional patterns of microbial species may be among the properties well worth considering as characters to use in classification'.

The end of World War II in Europe occurred on 8 May 1945. Knight was very francophilic (many holidays were spent in his favourite haunts in the Dordogne) and he must have been very honoured and delighted to receive invitations from La Société de Chimie biologique and from L'Institut Pasteur to lecture in Paris in July 1945. He introduced his first lecture on 'Les métabolites essentials et les anti-métabolites' with the following most appropriate remarks: 'Je voudrais commencer par dire combien je suis sensible à l'honneur de pouvoir vous parler aujourd'hui, et quel plaisir j'éprouve à aider à rétablir les liens scientifiques entre nos deux pays. Lire du français a toujours été un de rises grands plaisirs; mais il y a une grande différence entre lire une langue et la parler. J'espère que vous excuserez mes fautes de prononciation'. His second lecture on the following day, also delivered in French, was on 'La formation des toxines par les bactéries'. In the following year he again visited Paris to contribute a paper 'Pasteur et l'étude des toxines bactériennes' at the Congress held to commemorate the 50th anniversary of Pasteur's death.

In 1945 Knight published his second major monograph entitled Growth Factors in Microbiology. Some Wider Aspects of Nutritional Studies with Microorganisms. This 109-page work was a very valuable review of a subject which had grown rapidly since the appearance of his 1936 pioneering monograph and it maintained his international reputation as a leading authority in this field. Although he recognized that more growth factors would be discovered (and perhaps the most notable is $\mathrm{B}_{12}$, finally crystallized in 1948 but whose structure was not elucidated until 1957), Knight believed that an era was closing in that: 'It is clear that the initial stage of discovering essential metabolites is now passing to a higher stage. The emphasis can now be placed on the purposeful study of the physiological functions of essential metabolites'. This, together with the study of the regulation of function, is more or less what has happened since 1945. The final sentence of this monograph illustrates his unifying philosophy: 'Such studies with microorganisms are of the widest value since the findings, reflecting the unity of all biochemistry, will have applications in all biological fields'. And what could be more true in the present era of molecular biology/recombinant DNA technology?

Knight enjoyed some four months in the U.S.A. from October 1947 to January 1948 as Visiting Commonwealth Professor, New York College of Medicine. In the November he delivered a Harvey Lecture on 'Bacterial Chemistry and Evolution' during which he emphasized the view that 'growth factors were essential ingredients of all living cells in which they were found, whether or not they were synthesized endogenously' and they 'are parts of universally- 
used metabolic mechanisms'. On evolution, Knight pointed out that whilst both he and Lwoff had independently concluded in the early 1930s that the gradation from simple to complex nutrient requirements reflected an evolutionary loss of biosynthetic function, the major difficulty in accepting this as a corresponding phylogenetic series is that an organism's 'biosynthetic ability is as great as its nutritional requirements are simple'. This therefore seemed to exclude the possibility that the autotrophs were the most primitive organisms on earth and 'it seems more reasonable to think that the first self-replicating unit was evolved in an environment of complex carbon compounds formed from geochemical reactions'. Oparin and J. B. S. Haldane had proposed in the early 1920s that complex organic compounds could have been formed in the presumed conditions of the primitive earth, but the celebrated experiments of Stanley Miller were not done until 1953. In January 1948 Knight delivered the William Henry Welch Lecture at the Mount Sinai Hospital, New York; some 56 years earlier Welch and Nuttall had isolated and given the first complete description of Clostridium welchii. Although Knight was well-known for his work on clostridia he nevertheless chose to talk about his other love, 'Essential Metabolites and Anti-metabolites'. Once again he emphasized that 'a nutritional requirement reflected an inability to synthesize a universally required substance'. Nutritional studies could help to identify their nature, and interference with their synthesis or function could be lethal to the bacterium. Hence the search for anti-metabolites about which he commented: -At least this theoretical approach has the merit of emphasising and defining in a concrete way one kind of target in an organism to be attacked, namely its essential metabolic processes. The study of growth factors is one way of finding out what some of these metabolic processes are'.

In the early 1940s Knight was seriously concerned that microbiology was not regarded as a separate and unified discipline, that there were no courses for teaching it as one in the U.K., and that there was no central meeting place in the U.K. for the wide variety of practising microbiologists. He believed, as did many others, that the 'grave subdivisions of the subject' had been brought about by (1) the importance of the different fields of application, and (2) the teaching and study of the different microbial forms as parts of different disciplines, e.g. algae and fungi as parts of botany, bacteriology in medical schools, viruses with plant and animal pathology, protozoa as part of zoology. His concern and his activities associated with these matters contributed significantly to the founding of the Society for General Microbiology (SGM) in 1945 and of the Journal of General Microbiology in 1947, and to his appointment in 1951 as the first Professor of Microbiology in the first university Department of Microbiology in the U.K. at Reading. He participated in the preliminary discussions which led to the Inaugural Meeting of the SGM in February 1945. At this meeting Sir Alexander Fleming was elected the first president of the Society and Knight was elected with 10 others to membership of its first committee. Sir Alexander made a particularly appropriate comment during his presidential address: 'The new Society has been born into a troublous world, and the shortage of paper - an essential metabolite! - would prevent it immediately embarking on the venture of a new journal'. Knight must nevertheless have been sharpening a new set of blue pencils ... the Biochemical Society had constituted its first Editorial Board of eight members in 1943 and he was one of them (serving until 1947), and in 1946 the SGM appointed him Joint Editor, with A. A. Miles, of the new Journal of General Microbiology. The first volume appeared in 1947 and he remained an Editor of the Journal for the next 23 years, with A. F. B. Standfast for all but five years. He and his co-editors were sticklers for proper grammar, syntax, conciseness, clarity, typography, and indeed for everything connected with editing. This led to their being condemned by more than one contributor for their 'ruthless editing of excellently written papers'. In 1954 they elevated to item number one of the 'Directions to Contributors' their plea for conciseness and clarity and at the same time introduced Knight's beautiful parody of Sheridan's 'Easy writing's curst hard reading' in the form 'Easy reading's curst hard writing'.

Knight firmly believed in the comparative study of microbial forms and the new SGM and its journal provided an excellent forum for encouraging and achieving this. The thread of comparative microbiology can be traced in his earlier writings on microbial nutrition, in his comparative survey of the genus Bacillus and, in a wider sense, in his organizing and editing with H. P. Charles in 1970 of the 20th SGM Symposium on 'Organization and Control in Prokaryotic and Eukaryotic Cells: 
Knight was fascinated by the more unusual microbial forms. Such unusual organisms are often more difficult to handle in the laboratory; because of this they are often much less studied and so much less is known about them or (Catch 22) how to handle them in the laboratory. Charles and Knight in their preface to the 20th SGM Symposium expressed the opinion that 'much greater knowledge of the less studied groups of microorganisms' will be required for a deeper understanding of the interrelationship between eukaryotes and prokaryotes. In 1951 PPLOs (mycoplasmas) were an example of a more unusual and relatively little studied microbial form. Knight brought an interest in these organisms with him to Reading from the Wellcome Laboratories having been made aware of their unusual nutritional requirements (e.g. for cholesterol) by D. G. ff. Edward who had been working with them since about 1940. The only other major study of these organisms was being done by Emmy Klieneberger-Nobel at the Lister Institute. Klieneberger-Nobel had arrived in London in 1933 as a refugee from Nazi Germany. She knew nobody in England but had been recommended to get in touch with Knight, who at that time was working with Fildes at the London Hospital, by an acquaintance who had met him at a conference. Knight recommended that she should try the Lister Institute and this resulted in an offer of accommodation by the Director, J. C. G. Ledingham, who proposed that she should work on PPLOs. Within two weeks of her arrival in London she started work there. She remained at the Lister for the rest of her working life (29 years), and became an, if not the, international authority and doyenne on PPLOs.

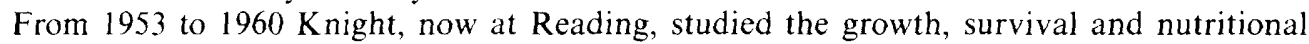
requirements of PPLOs with $\mathrm{M}$. Butler and then with S. Razin. The partially defined medium of Razin and Knight was particularly useful for the study of nutritional requirements and its use led to the conclusion that cholesterol might not be required for saprophytic strains. This was a particularly significant observation because four years earlier Edward and Freundt had stressed the importance of the cholesterol requirement as a criterion for distinguishing mycoplasmas from other bacteria. Subsequently the acholeplasmas were indeed shown not to require cholesterol. Razin had come from Israel to work for a year with Knight to learn about PPLOs with the aim, in the long term, of using their membranes as a model and tool in biomembrane studies. Razin has since become an internationally recognized authority in mycoplasmology.

Although Knight disliked administration he nevertheless held important and responsible University offices during his 18 years as Professor of Microbiology. He was Associate Dean of the Faculty of Science from 1954-56 and Dean from 1956-60. In 1959, during his Deanship, it gave Knight much pleasure to introduce and present his old chief and mentor Sir Paul Fildes for the Honorary degree of DSc. In 1963 the Government accepted the Robbins Report on higher education and Knight was elected a member of the Senate working party to consider its implications for the biological sciences in the University; its recommendations did much to determine the development of this area over the next decade. For the whole of his period at Reading Knight was a member of the Special Advisory Board in Microbiology of the University of London. As a Curator of the University Library from 1954 until his retirement in 1969, and as its chairman from 1963-68, he cared not only about balancing the books but also about the books themselves. He became intimately involved with the affairs of the library, as one would expect of such a bibliophile, a feature that was much appreciated by the library staff. In the less academic sphere he held office as Senior Steward of Senior Common Room and as President of the local branch of the Association of University Teachers.

Knight was a learned francophile. In 1937, using the pseudonym Jonathan Kemp, he translated, with Jean Stewart, Diderot, Interpreter of Nature. Selected Writings. He edited this work and wrote a 34-page introduction. He became an authority on the novelist Stendhal, about whom he wrote articles for Le Divan and Stendhal Club, and in 1958 he translated, with Jean Stewart, Stendhal's autobiographical Life of Henri Brulard. Indeed in the middle 1950s Henri Martineau, the principal editor of Stendhal and the best-known authority of the time, enquired of a colleague in Paris whether he had ever met or heard of this remarkable Englishman. Over the years Knight acquired a remarkable collection of Stendhaliana and of books on 18th-20th century French and English philosophy and literature, a monument to his erudition.

Knight's interest in unusual shapes and forms was also shown outside the laboratory. His study at home was adorned with numerous treasured pieces of objets trouvés and bric-à-brac 
including flints, pebbles, stones, wood, etc., having reminiscent or suggestive shapes. His own piece of composite abstract art consisted of a large butcher's hook from which hung precariously an off-cut from an iron pipe, rescued from the engineer's workshop waste-bin, together with a large lump of pitch. Over the years the latter showed unmistakable signs of flowing deformation and as the thing was suspended over the door one wondered which visitor was going to be unlucky.

Knight's imposing figure and his intimidating and gruff manner could be quite overwhelming. His pungent interjections at both formal and informal gatherings often had a devastating effect; they illustrated at once the agility of his mind, his fine sense of humour, and his colourful personality. Basically, however, he was a shy, kind and selfless man. He was an egalitarian and was enraged by affectation and snobbery of any kind. He aroused great affection and esteem in those who were fortunate enough to know him at all well. Both he and his wife Frida always made one feel so very welcome whenever one visited their home; they were always particularly pleased to see old friends in Cambridge when they moved there from Reading after his retirement.

L. J. ZATMAN

I thank friends and colleagues for the anecdotes and reminiscences of their association with B.C.J.K. I am indebted to Sidney Elsden who also provided the original minutes of the meetings of the initiators of the SGM that took place in 1943 and 1944 and for information about the early history of the Society. 